\title{
Wine and Food in European Union Law
}

\author{
Konrad Schiemann
}

(C) ERA 2011

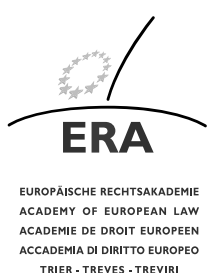

Abstract "It would be possible to organise a useful course on European Union Law using only cases involving wine and food." Starting from this assumption, the author designs an imaginative picnic in Burgundy where a fine selection of food and wines inspires an equally exquisite recollection of classical cases from the jurisprudence of the European Court of Justice, all originating from a legal problem with an agricultural or oenological product. Far from being exhaustive, this entertaining compilation illustrates how copious the stock still is.

Keywords Wine · Food - European Union law · Protected denominations of origin · Trademarks

\section{Introduction}

Last year Quentin Letts wrote ${ }^{1}$ of the Right Honourable Kenneth Clark QC sitting in the House of Commons "His countenance is seldom less red than a tumbler of Campari but at this point it turned to something more approximate to the scarlet of Clos Toulmin Pinot Noir 2004". I mention this not to launch a discourse on the physiognomy of the present Lord Chancellor but rather to indicate that the vinous products of John Toulmin - vigneron d'Auxey-Duresses - are as well known as the judicial products of John Toulmin QC, sitting in the High Court of England and Wales. I am in the happy position of having more than sampled both.

\footnotetext{
${ }^{1}$ Daily Mail 20 January 2009.

Sir K. Schiemann M.A. LLB, Judge at the Court of Justice of the European Union ( $\varangle$ ) Court of Justice of the European Union, Kirchberg, 2925 Luxembourg, Luxembourg e-mail: Konrad.Schiemann@curia.europa.eu
} 
It is something of an achievement for an Englishman to set himself up as a vigneron in Burgundy. Hugh Johnson, who has a farm in central France, reveals in his delightful "Wine: a life uncorked", that "Riesling I had first thought would be the grape to plant in my vineyard, simply because I like the taste. It might ripen well in our spells of late sunshine. Luxembourg can sometimes do it, and that is far colder and further north. At any rate it was only for the family, many kilometres from any recognised region, so why would anyone mind? I had underestimated your French bureaucrat. "Pas autorisé, Monsieur" means "Just you try it, son". If I'd said Sauvignon Blanc and planted Riesling (and burned the dockets) would they ever have known? The police don't knock when they wander about our land with binoculars looking for poachers. Not worth the risk." John, so far as I know, has followed this cautious approach - as befits anyone who has more than a passing acquaintance with the complexity of the European Union's regulations governing wine.

When the European Economic Community was formed each member nation had its own regulations. Not that each nation had merely one set of regulations. Far from it. Many had a multitude and for many of the rules in each regulation there was, a whole host of exceptions. Yet each provision was in some sense a barrier to trade and thus had to be justified if it were to pass the scrutiny of the Court of Justice. This was potentially extremely tedious and so attempts have been made over the past 50 years by politicians to establish European wide rules. The rules cover a large variety of fields - including various measures which try to match supply and demand so as to avoid wine lakes and eliminate wasteful public intervention in the markets and redirect spending so as to make European wine more competitive. For those who have a taste for the complexities of this kind of exercise I would recommend a perusal of the pertinent regulations as amended. Their titles give one the general feel. ${ }^{2}$ Like all such regulations they are the result of political compromises, reached after years of negotiations, between conflicting aims resulting in texts of mind numbing complexity. The end result is a broad structure which for labelling purposes divides wines into two categories - wines with geographical indications and wines without geographical indications - and divides the former into two subcategories, namely, wines with a protected designation of origin (PDO and its equivalent in other languages) and wines with the slightly looser protected geographical indication (PGI and its equivalents). However, in substance the use of the new terminology appears to be optional and so the old regimes may well carry on in parallel.

Actually reading the regulations is something I personally only do in the line of duty. ${ }^{3}$ Since food and wine are an important part of life, and the Common Agricultural

\footnotetext{
${ }^{2}$ Commission Regulation (EC) No 436/2009 of 26 May 2009 laying down detailed rules for the application of Council Regulation (EC) No 479/2008 as regards the vineyard register, compulsory declarations and the gathering of information to monitor the wine market, the documents accompanying consignments of wine products and the wine sector registers to be kept; Commission Regulation (EC) No 606/2009 of 10 July 2009 laying down certain detailed rules for implementing Council Regulation (EC) No 479/2008 as regards the categories of grapevine products, oenological practices and the applicable restrictions; and Commission regulation (EC) No 607/2009 of 14 July 2009 laying down certain detailed rules for the implementation of Council Regulation (EC) No 479/2008 as regards protected designations of origin and geographical indications, traditional terms, labelling and presentation of certain wine sector products.

${ }^{3}$ A more agreeable read is an article by Julia Harding, Master of Wine, dated 3.11.2010 which can be found at JancisRobinson.com - which she suggests can best be appreciated glass in hand.
} 
Policy consumes some $40 \%$ of the European Union's budget, it is not surprising that a significant part of the caseload of the Union's Court has concerned such matters. Late one evening as I was reading my way through one such regulation with a glass of Clos Toulmin in my hand I fear I fell asleep. I found myself dreaming that I was attending a picnic in Burgundy with John and a French friend. I noticed that all the food and drink which John had unpacked from his rucksack brought to mind some case or other elucidating the principles of European Union law.

\section{Protected Designations of Origin, Fundamental Rights and Trademarks}

Happily I had momentarily forgotten about the regulation which I was trying to construe with the aid of the Court's dense case law. Instead I was introducing the Frenchman to the easy judicial style of Lord Denning with which I grew up. Here are the opening paragraphs of his judgment in H.P Bulmer v J Bollinger SA. ${ }^{4}$

"In France the name Champagne is well protected by law. It denotes a sparkling wine produced in a well favoured district of France, called the Champagne district. The vineyards are about a hundred miles east of Paris, around Reims and Epernay. The wine has a high reputation all the world over.

In England, too, the name Champagne is well protected by law when used for wine. As far back as 1956 some intruders brought into England a somewhat similar wine. It had been produced in the Costa Brava district of Spain. They marketed it under the name 'Spanish Champagne'. The French growers and shippers brought an action to stop it. They succeeded. Mr. Justice Danckwerts held that the French growers had a goodwill connected with the word Champagne: and that the Spanish intruders had been guilty of dishonest trading, see Bollinger v. Costa Brava (1960) Ch 262....

That case in 1960 concerned wine - wine made from grapes - for which the French are so famous. Now we are concerned with cider and perry. Cider from apples. Perry from pears. We English do know something about these. At any rate, those who come up from Somerset or Herefordshire.

For many years now some producers of cider in England have been marketing some of their drinks as 'champagne cider' and 'champagne perry'. When it started the French producers of champagne took no steps to stop it. It went on for a long time. But in 1970 the French producers brought an action against an English firm, claiming an injunction. They sought to stop the use of the name Champagne on these drinks. To counter this, two of the biggest producers of cider in England on 8th October, 1970 brought an action against the French producers. They claimed declarations that they were entitled to use the expression 'Champagne cider' and 'Champagne perry'. They said that they had used those expressions for 70 or 80 years in England; that many millions of bottles had been marketed under those descriptions; and that the Government of the United Kingdom had recognised it in the various regulations. They said further

${ }^{4}[1974]$ EWCA Civ 14. 
that the French producers had acquiesced in the use and were estopped from complaining.

In answer the French producers of Champagne claimed that the use of the word 'Champagne' in connection with any beverage other than Champagne was likely to lead to the belief that such beverage was or resembled Champagne, or was a substitute for it, or was in some way connected with Champagne. They claimed an injunction to stop the English producers from using the word 'Champagne' in connection with any beverage not being a wine produced in the Champagne district of France.

Thus far it was a straightforward action for passing-off. It was to be determined by well-known principles of English law. But on 1st January, 1973, England joined the Common Market. On 26th March, 1973, the French producers amended their pleading so as to add these claims:

'9A Following the adhesion of the United Kingdom to the European Economic Community the use of the word 'Champagne' in connection with any beverage other than Champagne will contravene European Community Law.'

They relied on Regulation 816/76/Article 30 and Regulation 817/70 Article $628 / 12$ and $13 . .$.

"The French producers claim that, under those regulations, the name Champagne is their own special property. It must not be applied to any wine which is not produced in the Champagne District of France. So much the English producers concede. But the French producers go further. They say that the name Champagne must not be applied to any beverage other than their Champagne. It must not, therefore, be applied to cider or perry, even though they are not wines at all. The English producers deny this. They say that the Regulations apply only to wines - the product of grapes - and not to cider or perry - the product of apples and pears.

This is obviously a point of the first importance to the French wine trade and to the English cider trade. It depends no doubt on the true interpretation of the Regulations. It seems that three points of principle arise:

First. By which Court should these Regulations be interpreted? By the European Court at Luxembourg? or by the national Courts of England?

Second. At what stage should the task of interpretation be done? Should it be done now before the case is tried out in the English Court? or at a later stage after the other issues have been determined?

Third. In any case, whichever be the Court to interpret them, what are the principles to be applied in the interpretation of the Regulations? If we were to interpret the Regulations as if they were an English statute, I should think they would apply only to wines, not to cider or perry. But, if other principles were to be applied, the result might be different. That is indeed what the French producers say. They contend that the European Court can fill in any gaps in the Regulations. So that the words can be extended so as to forbid the use of the word 'Champagne' on cider or perry. That is, no doubt, the reason why the French producers want the point to be referred here and now to the European Court." 
The conclusion of the court of appeal was that the first instance judge had been entitled to refuse to refer. ${ }^{5}$

John had of course produced some excellent champagne and we talked of the many attempts which had been made to share in the glow of champagne by those outside the region. To regulate this the Community had made some regulation restricting the use of the phrase "méthode champenoise". The validity of this was challenged by the makers of a German sparkling wine in SMW Winzersekt GmbH v Land RheinlandPfalz. ${ }^{6}$ The Court considered the extent of the right to property and the freedom to pursue a trade or profession, the extent of the discretion vested in the Commission, the nature of the control of proportionality applied by the Court to restrictions of those freedoms and the purpose behind the wine labelling regulations. The Court said this:

"19 It follows from the documents on the case-file and the arguments before the Court that the validity of the second and third subparagraphs of Article 6(5) of Regulation No 2333/92 has been challenged in the light of two principles or groups of principles: on the one hand, the right to property and the freedom to pursue a trade or profession and, on the other, the general principle of equal treatment.

\section{The right to property and the freedom to pursue a trade or profession}

20 Winzersekt takes the view that the contested provision adversely affects both its right to property and its right freely to pursue a trade or profession, which form part of the general principles of Community law. It submits in that connection that the designation 'méthode champenoise' is of fundamental importance for its commercial activity in so far as that designation enables it to make the public aware of its method of production....

21 It should be pointed out in this respect that in matters concerning the common agricultural policy the Community legislature has a broad discretion which corresponds to the political responsibilities given to it by Articles 40 and 43 of the Treaty and that the Court has, on several occasions, held that the lawfulness of a measure adopted in that sphere can be affected only if the measure is manifestly inappropriate, having regard to the objective which the competent institution is seeking to pursue....

22 Account must also be taken of the Court's case-law to the effect that the right to property and the freedom to pursue a trade or business are not absolute but must be viewed in relation to their social function. Consequently, the exercise of the right to property and the freedom to pursue a trade or profession may be restricted, particularly in the context of the common organisation of a market, provided that those restrictions in fact correspond to objectives of general interest pursued by the Community and do not constitute a disproportionate and intolerable interference, impairing the very substance of the rights guaranteed....

\footnotetext{
${ }^{5}$ The case was referred back to the trial judge to try the issue whether there had been a passing off under English domestic law. He found that there had been. However this finding was reversed, so far as champagne perry was concerned, by the Court of appeal: [1978] RPC 79.

${ }^{6}$ Case C-306/93 [2004] ECR 1-05555.
} 
23 With regard to the infringement of the right to property alleged by Winzersekt, the designation 'méthode champenoise' is a term which, prior to the adoption of the regulation, all producers of sparkling wines were entitled to use. The prohibition of the use of that designation cannot be regarded as an infringement of an alleged property right vested in Winzersekt.

24 So far as concerns the impairment of the freedom to pursue a trade or profession, the second and third subparagraphs of Article 6(5) of Regulation No 2333/92 do not impair the very substance of the right freely to exercise a trade or profession relied on by Winzersekt since those provisions affect only the arrangements governing the exercise of that right and do not jeopardise its very existence. It is for that reason necessary to determine whether those provisions pursue objectives of general interest, do not affect the position of producers such as Winzersekt in a disproportionate manner and, consequently, whether the Council exceeded the limits of its discretion in this case.

25 It should be noted in this regard that among the objectives pursued by Regulation No 2333/92, that of the protection of registered designations or indications of the geographical origin of wines is an objective of general interest. In order to achieve that objective, the Council was entitled to regard it as essential, on the one hand, that the final consumer should receive sufficiently accurate information to enable him to form an opinion of the products in question and, on the other hand, that the producer should not derive advantage, for his own product, from a reputation established for a similar product by producers from a different region. This implies that a wine producer cannot be authorised to use, in descriptions relating to the method of production of his products, geographical indications which do not correspond to the actual provenance of the wine.

26 That objective is implemented in particular by Article 6 of Regulation No 2333/92, which provides that the use of terms relating to a production method may refer to the name of a geographical unit only where the wine in question is entitled to use that geographical indication.

27 It follows that the prohibition laid down in that provision is not manifestly inappropriate in relation to the objective of the regulation at issue.

28 Furthermore, by adopting transitional arrangements such as those set out in the third subparagraph of Article 6(5) of the regulation and by allowing producers who, like Winzersekt, used the designation 'méthode champenoise' to have recourse to the alternative expressions contained in Article 6(4) of Regulation No 2333/92, such as 'bottle-fermented by the traditional method', 'traditional method', 'classical method' or 'classical traditional method' and any expressions resulting from a translation of those terms, the Council took account of the position of those producers. In those circumstances, the contested provision cannot be regarded as disproportionate.

29 It follows that the second and third subparagraphs of Article 6(5) of Regulation No 2333/92 pursue objectives of general interest and cannot be regarded as constituting a disproportionate interference with the position of producers such as Winzersekt. In those circumstances, it must be held that the Council did not exceed the limits of its discretion in adopting those provisions. 


\section{The general principle of equal treatment}

30 In this regard, the Court has consistently held that the principle of equal treatment requires that similar situations should not be treated differently and that different situations should not be treated identically unless such differentiation is objectively justified....

31 In the present case, the second and third subparagraphs of Article 6(5) of Regulation No 2333/92 apply to all producers of sparkling wines in the Community with the exception of those who are entitled to use the registered designation 'Champagne'. The fact of entitlement to use that registered designation is an objective matter which can justify a difference in treatment. In those circumstances, a difference in the treatment of each of those two groups of producers is justified.

32 The reply to the national court must accordingly be that examination of the question submitted has not revealed any factor of such a kind as to affect the validity of the second and third subparagraphs of Article 6(5) of Council Regulation No 2333/92."

We agreed that it must not be thought that the ECJ would uphold the wine regulations come what may. This is shown by Codorníu SA v Council of the European Union ${ }^{7}$ which has been referred to in innumerable cases and articles thereafter. Codorníu successfully challenged the validity of a regulation which allowed the use of the word "Crémant" only in respect of sparkling wines from France or Luxembourg and thus forbad its use in respect of wines emanating from Spain. The case raised two issues. The first concerned the standing of Cordoníu to apply for such an annulment. The second the legality of the discrimination between France and Luxembourg on the one hand and Spain on the other.

As to admissibility the Court said this:

"19 Although it is true that according to the criteria in the second paragraph of Article 173 of the Treaty the contested provision is, by nature and by virtue of its sphere of application, of a legislative nature in that it applies to the traders concerned in general, that does not prevent it from being of individual concern to some of them.

20 Natural or legal persons may claim that a contested provision is of individual concern to them only if it affects them by reason of certain attributes which are peculiar to them or by reason of circumstances in which they are differentiated from all other persons...

21 Codorníu registered the graphic trade mark 'Gran Cremant de Codorníu' in Spain in 1924 and traditionally used that mark both before and after registration. By reserving the right to use the term 'crémant' to French and Luxembourg producers, the contested provision prevents Codorníu from using its graphic trade mark.

22 It follows that Codorníu has established the existence of a situation which from the point of view of the contested provision differentiates it from all other traders.

${ }^{7}$ Case C-309/89 [1994] ECR 1-01853. 
23 It follows that the objection of inadmissibility put forward by the Council must be dismissed."

As regards the plea of unlawful discrimination the Court said this:

"26 It is appropriate in the first place to point out that under the principle of non-discrimination between Community producers or consumers, which is enshrined in the second subparagraph of Article 40(3) of the EEC Treaty and which includes the prohibition of discrimination on grounds of nationality laid down in the first paragraph of Article 7 of the EEC Treaty, comparable situations must not be treated differently and different situations must not be treated in the same way unless such treatment is objectively justified. It follows that the conditions of production or consumption may not be differentiated except by reference to objective criteria which ensure a proportionate division of the advantages and disadvantages for those concerned without distinction between the territories of the Member States...

27 The contested provision provides that the term 'crémant' in combination with the name of the specified region shall be reserved for quality sparkling wines psr made in France or Luxembourg which satisfy the conditions provided for in the second paragraph of Article 6(4) of Regulation No 3309/85 and which were produced in accordance with the special rules laid down for their manufacture by those two Member States.

28 It thus appears that the term 'crémant' refers primarily not to the origin but the method of manufacture of the quality sparkling wine psr, in particular that provided for in Article 6(4) of Regulation No 3309/85. Since the quality sparkling wines psr sold under the Spanish graphic trade mark 'Gran Cremant de Codorníu' satisfy the conditions provided for by the contested provision, it follows that provision treats comparable situations differently.

29 It is therefore necessary to ascertain whether such treatment was objectively justified.

30 In that respect the reason given for the reservation of the term 'crémant' was concern to protect a description traditionally used in France and Luxembourg for products of specific origin.

31 It is common ground that the first national measures providing in France and Luxembourg for the use of the term 'crémant' as a 'traditional description' were adopted in 1975. Codorníu, however, has been traditionally using its graphic trade mark containing the words 'Gran Cremant' to designate a quality sparkling wine psr since at least 1924.

32 In those circumstances the reservation of the term 'crémant' for quality sparkling wines psr manufactured in France and Luxembourg cannot validly be justified on the basis of traditional use, since it disregards the traditional use of that mark by Codorníu.

33 The Commission observes, however, that it follows from the wording of the contested provision, according to which the term 'crémant' must be followed by specification of the region of production, that the term 'crémant' refers not so much to the method of manufacture of a quality sparkling wine psr as to its origin. 
34 In that respect it must be observed that according to the contested provision the term 'crémant' is in essence attributed on the basis of the method of manufacture of the product, since the specification of the region of production serves only to indicate the origin of the quality sparkling wine psr. The origin thus has nothing to do with the attribution of the term 'crémant', which is not associated with a geographical connection.

35 The different treatment has therefore not been objectively justified and the contested provision must be declared void.

36 In view of the foregoing it does not appear necessary to consider the other pleas in law put forward by Codorníu."

\section{Challenging the Validity of Community Regulations}

As we poured a few drops of olive oil on our salad we called to mind $P$ Unión de Pequeños Agricultores $v$ Council of the European Union ${ }^{8}$ where the Court was once more concerned with the standing of the claimant to challenge the validity of a Community regulation. In this context the Court considered the impact of the standing rules on the right to effective legal protection and also considered the principle of sincere cooperation. The court said this:

"32 As a preliminary point, it should be noted that the appellant has not challenged the finding of the Court of First Instance, in paragraph 44 of the contested order, to the effect that the contested regulation is of general application. Nor has it challenged the finding, in paragraph 56 of that order, that the specific interests of the appellant were not affected by the contested regulation or the finding, in paragraph 50 of that order, that its members are not affected by the contested regulation by reason of certain attributes which are peculiar to them or by reason of factual circumstances in which they are differentiated from all other persons.

33 In those circumstances, it is necessary to examine whether the appellant, as representative of the interests of its members, can none the less have standing, in conformity with the fourth paragraph of Article 173 of the Treaty, to bring an action for annulment of the contested regulation on the sole ground that, in the alleged absence of any legal remedy before the national courts, the right to effective judicial protection requires it.

34 It should be recalled that, according to the second and third paragraphs of Article 173 of the Treaty, the Court is to have jurisdiction in actions brought by a Member State, the Council or the Commission on grounds of lack of competence, infringement of an essential procedural requirement, infringement of the Treaty or of any rule of law relating to its application, or misuse of powers or, when it is for the purpose of protecting their prerogatives, by the European Parliament, by the Court of Auditors and by the European Central Bank. Under the fourth paragraph of Article 173, '[a]ny natural or legal person may, under

${ }^{8}$ Case C-50/00 [1-06677]. 
the same conditions, institute proceedings against a decision addressed to that person or against a decision which, although in the form of a regulation or a decision addressed to another person, is of direct and individual concern to the former.'

35 Thus, under Article 173 of the Treaty, a regulation, as a measure of general application, cannot be challenged by natural or legal persons other than the institutions, the European Central Bank and the Member States ...

36 However, a measure of general application such as a regulation can, in certain circumstances, be of individual concern to certain natural or legal persons and is thus in the nature of a decision in their regard... That is so where the measure in question affects specific natural or legal persons by reason of certain attributes peculiar to them, or by reason of a factual situation which differentiates them from all other persons and distinguishes them individually in the same way as the addressee...

37 If that condition is not fulfilled, a natural or legal person does not, under any circumstances, have standing to bring an action for annulment of a regulation ...

38 The European Community is, however, a community based on the rule of law in which its institutions are subject to judicial review of the compatibility of their acts with the Treaty and with the general principles of law which include fundamental rights.

39 Individuals are therefore entitled to effective judicial protection of the rights they derive from the Community legal order, and the right to such protection is one of the general principles of law stemming from the constitutional traditions common to the Member States. That right has also been enshrined in Articles 6 and 13 of the European Convention for the Protection of Human Rights and Fundamental Freedoms ...

40 By Article 173 and Article 184 ..., on the one hand, and by Article 177, on the other, the Treaty has established a complete system of legal remedies and procedures designed to ensure judicial review of the legality of acts of the institutions, and has entrusted such review to the Community Courts ... Under that system, where natural or legal persons cannot, by reason of the conditions for admissibility laid down in the fourth paragraph of Article 173 of the Treaty, directly challenge Community measures of general application, they are able, depending on the case, either indirectly to plead the invalidity of such acts before the Community Courts under Article 184 of the Treaty or to do so before the national courts and ask them, since they have no jurisdiction themselves to declare those measures invalid ... to make a reference to the Court of Justice for a preliminary ruling on validity.

41 Thus it is for the Member States to establish a system of legal remedies and procedures which ensure respect for the right to effective judicial protection.

42 In that context, in accordance with the principle of sincere cooperation laid down in Article 5 of the Treaty, national courts are required, so far as possible, to interpret and apply national procedural rules governing the exercise of rights of action in a way that enables natural and legal persons to challenge before 
the courts the legality of any decision or other national measure relative to the application to them of a Community act of general application, by pleading the invalidity of such an act.

$43 \ldots$ it is not acceptable to adopt an interpretation of the system of remedies, such as that favoured by the appellant, to the effect that a direct action for annulment before the Community Court will be available where it can be shown, following an examination by that Court of the particular national procedural rules, that those rules do not allow the individual to bring proceedings to contest the validity of the Community measure at issue. Such an interpretation would require the Community Court, in each individual case, to examine and interpret national procedural law. That would go beyond its jurisdiction when reviewing the legality of Community measures.

44 Finally, it should be added that, according to the system for judicial review of legality established by the Treaty, a natural or legal person can bring an action challenging a regulation only if it is concerned both directly and individually. Although this last condition must be interpreted in the light of the principle of effective judicial protection by taking account of the various circumstances that may distinguish an applicant individually ..., such an interpretation cannot have the effect of setting aside the condition in question, expressly laid down in the Treaty, without going beyond the jurisdiction conferred by the Treaty on the Community Courts....

46 In the light of the foregoing, the Court finds that the Court of First Instance did not err in law when it declared the appellant's application inadmissible without examining whether, in the particular case, there was a remedy before a national court enabling the validity of the contested regulation to be examined."

\section{Protected Designations of Origin Revisited: The Parma Ham Case}

It was now time for some strengthening food and we turned to consider the Parma ham which was beautifully packed and which awaited our attention. We recalled that in relation to the protection granted by designations of origin the Court in Consorzio del Prosciutto di Parma and Salumificio S. Rita SpA v Asda Stores Ltd and Hygrade Foods Ltd. ${ }^{9}$ had said this:

"62. It should be noted that, in accordance with Article 30 EC, Article 29 EC does not preclude prohibitions or restrictions on exports which are justified inter alia on grounds of the protection of industrial and commercial property. 63. Community legislation displays a general tendency to enhance the quality of products within the framework of the common agricultural policy, in order to promote the reputation of those products through inter alia the use of designations of origin which enjoy special protection... That tendency took the

${ }^{9}$ Case C-108/01 [2003] ECR 1-05121. 
form in the quality wines sector of the adoption of Council Regulation (EEC) No 823/87 of 16 March 1987 laying down special provisions relating to quality wines produced in specified regions ... repealed and replaced by Council Regulation (EC) No 1493/1999 of 17 May 1999 on the common organisation of the market in wine... It was also manifested, in relation to other agricultural products, in the adoption of Regulation No 2081/92, which, according to its preamble, is intended inter alia to meet consumers' expectations as regards products of quality and an identifiable geographical origin and to enable producers, in conditions of fair competition, to secure higher incomes in return for a genuine effort to improve quality.

64. Designations of origin fall within the scope of industrial and commercial property rights. The applicable rules protect those entitled to use them against improper use of those designations by third parties seeking to profit from the reputation which they have acquired. They are intended to guarantee that the product bearing them comes from a specified geographical area and displays certain particular characteristics. They may enjoy a high reputation amongst consumers and constitute for producers who fulfil the conditions for using them an essential means of attracting custom. The reputation of designations of origin depends on their image in the minds of consumers. That image in turn depends essentially on particular characteristics and more generally on the quality of the product. It is on the latter, ultimately, that the product's reputation is based... For consumers, the link between the reputation of the producers and the quality of the products also depends on his being assured that products sold under the designation of origin are authentic.

65. The specification of the PDO 'Prosciutto di Parma', by requiring the slicing and packaging to be carried out in the region of production, is intended to allow the persons entitled to use the PDO to keep under their control one of the ways in which the product appears on the market. The condition it lays down aims better to safeguard the quality and authenticity of the product, and consequently the reputation of the PDO, for which those who are entitled to use it assume full and collective responsibility.

66. Against that background, a condition such as at issue must be regarded as compatible with Community law despite its restrictive effects on trade if it is shown that it is necessary and proportionate and capable of upholding the reputation of the PDO 'Prosciutto di Parma'...

78. Consequently, the condition of slicing and packaging in the region of production, whose aim is to preserve the reputation of Parma ham by strengthening control over its particular characteristics and its quality, may be regarded as justified as a measure protecting the PDO which may be used by all the operators concerned and is of decisive importance to them ...

79. The resulting restriction may be regarded as necessary for attaining the objective pursued, in that there are no alternative less restrictive measures capable of attaining it." 


\section{Precedence of EU Law, State Liability and Other Delicacies}

Inspired by Amministrazione delle Finanze dello Stato v Simmenthal $S p A,{ }^{10}$ decided in the context of veterinary regulations governing the import of Veal and Beef into Italy, we started talking about the principles laid down there which have been followed ever since. This led to a long discussion of the interrelation of Union law with national law, the obligation of national judges to apply Union law notwithstanding a conflict with national law. The discussion became involved and at this point John produced a bottle labelled Tocai friulano from Italy (now a little past its best it must be said) and another labelled Tocaj from Hungary. We tried the Italian one first with the remains of our salad and kept the Hungarian one for later. We called to mind Regione autonoma Friuli-Venezia Giulia and Agenzia regionale per lo sviluppo rurale (ERSA) v Ministero delle Politiche Agricole e Forestali ${ }^{11}$ and I remembered that the Court had there ruled on homonymity - a word which, after the Tocai friuliana seemed difficult to pronounce with my accustomed clarity - and had ruled that a Commission decision preventing the Italians from continuing to use the word tocai as from a date in 2007 was lawful.

But John's rucksack was not yet exhausted and he fished out some bananas which we could eat with the Royal Tokaji Aszú 6 Puttonyos. Bananas, he pointed out, qualified as part of this meal under several heads. For a start, there was the leading competition United Brands Company $v$ Commission, ${ }^{12}$ an early case in the bananas litigation which continues to reverberate down the Union's legal corridors. ${ }^{13}$

At this point my head started swimming with cases all concerned with food or drink in some of which John or I had been concerned at one stage or another - Dassonville ${ }^{14}$ and Cassis de Dijon ${ }^{15}$ which started a whole line of case law in relation to measures having an equivalent effect to quantitative restrictions, Commission $v$ France $^{16}$ and Commission $v U K^{17}$ on differential taxation as between spirits, wine and beer, Joined Cases Brasserie du Pêcheur and Factortame ${ }^{18}$ which laid down the ground rules for the civil liability of a Member State for breach of Union rules, Courage v Crehan ${ }^{19}$ which was concerned with the rights of a party to a tied-house agreement unlawful under Community law to sue the other contracting party and Marks \& Spencer Ltd $v$ Commissioners of Excise ${ }^{20}$ dealing with the principles of effectiveness and legitimate expectation.

\footnotetext{
${ }^{10}$ Case 106/77 [1978] ECR 00629.

${ }^{11}$ Case C-347/03 [2005] ECR 1-03785.

${ }^{12}$ Case 27/76 [1978] ECR 00207.

${ }^{13}$ See joined Cases C-120/06 p and C-121/06 P FIAMM [2008] ECR 1-06513.

${ }^{14}$ Case 8/74 [1974] ECR 00837.

${ }^{15}$ Case 120/78 [1979] ECR 00649.

${ }^{16}$ Case 168/78 [1980] ECR 00347.

${ }^{17}$ Case 170/78 [1983] ECR 02265.

${ }^{18}$ Cases C-46/93 and 48/93 [1996] ECR 1-01029.

${ }^{19}$ Case C-453/99 [2001] ECR 1- 06297.

${ }^{20}$ Case C-62/00 [2002] ECR 1-06325.
} 
I woke up with the happy thought that, should John after his retirement decide to organise a picnic course on European Union law from his delightful house in Burgundy, I might be invited - to eat and drink while listening to expositions by the next generation of Union lawyers. 